\title{
EFFECTS OF ADDING ACETIC ACID AND FEED WITHDRAWAL PERIOD ON GROWTH PERFORMANCE OF BROILER CHICKENS DURING THE SUMMER SEASON
}

\author{
G. A. A. Hamady, M. F. Taboosha and M. Y. M. Ali \\ Animal Production Department, Faculty of Agriculture, Al-Azhar University, Nasr City, Cairo, Egypt.
}

(Received 17/12/2019, accepted 25/2/2020)

\section{SUMMARY}

\begin{abstract}
$\mathrm{T}$ The present study evaluates the effects of feed withdrawal period and addition of acetic acid in drinking water on growth performance, physiological measurements, carcass traits, carcass chemical composition, intestinal microbial and economic efficiency of broiler chicks during the period of 22 to 42 days of age under Egyptian condition. A total number of 270 of Cobb broiler chick one day old were randomly assigned to six groups and fed a basal diet through the experimental period. The groups T1 (control), T2, T3, T4, T5 and T6 were fed ad libitum, fasting 8 hours, addition of 6\% acetic acid, fasting 8 hours with addition of $6 \%$ acetic acid, addition of $8 \%$ acetic acid and fasting 8 hours with addition of $8 \%$ acetic acid, respectively. The highest $(\mathrm{P}<0.05)$ final weight and weight gain were recorded for $\mathrm{T} 5$ group. While group T2 showed the lowest $(\mathrm{P}<0.05)$ value. The highest $(\mathrm{P}<0.05)$ averages of daily feed intake were reported by $\mathrm{T} 1, \mathrm{~T} 5$ and $\mathrm{T} 3$ groups. While, group $\mathrm{T} 2$ had $(\mathrm{P}<0.05)$ the lowest daily feed intake. The best feed conversion ratio $(\mathrm{P}<0.05)$ was recorded by the groups $\mathrm{T} 2$ and $\mathrm{T} 4$. Mortality rate was significantly the highest for the control. Blood serum traits are significantly affected by feeding dietary treatments within normal rage. Dressing carcass weight of T5 birds was significantly the highest compared to T2. Abdominal fat weight was significantly the highest for the control. The total bacteria account was $(\mathrm{P}<0.05)$ higher in birds treated acetic acid and the coliform bacteria was significantly lower. European production efficiency factor (EPEF) increased significantly for all treatments except the control. These results concluded that addition of acetic acids (6 and $8 \%$ ) with feed withdrawal ( 8 hours at 22-42 days of age) in drinking water during summer season have a positive effect on growth performance of broiler.
\end{abstract}

Keywords: Acetic acid, feed withdrawal, broiler performance and heat stress.

\section{INTRODUCTION}

Broiler chickens have a major share in the poultry production of Egypt. Overheating can lead to many physiological and metabolic variations in broilers that adversely impact broiler performance and immune response. Recently, proper nutrition management has led to a protective effect against heat stress. The dramatic improvements in growth rate, feed efficiency and meat yield of broiler chickens over the last few decades are primarily the result of genetic selection and improved nutrition (Tallentire et al., 2016, Zubair and Leeson 1996).

Unfortunately, along with these improvements have come unintended detrimental correlated responses such as an increase in appetite and excessive feed intake if broiler chickens are given free access to feed (Richards et al., 2003). Several quantitative and qualitative restricted-feeding programmers have therefore been employed in attempts to restrict feed intake of broilers in order to reduce feeding cost and fat deposition, improve feed efficiency, lessen the frequency of occurrence of metabolic diseases in the birds and reduce the unfavorable effects of fat on human health (Tolkamp et al., 2005 and Zhan et al., 2007). Feed restriction has been reported to reduce early growth, fat deposition and mortality rate and reduce the frequency of occurrence of these health problems (Navidshad et al., 2006 and Mahmud et al., 2008). Recent reports on feed restriction have been conflicting and have depended on factors such as the severity, timing, and duration of restriction (Navidshad et al., 2006 and Khajali et al., 2007). Long fasting periods after hatching have been shown to exert a strong influence on the performance of broilers (Sarica et al., 2014, Sarlak et al., 2017), retarding growth rates and muscle growth (Havely et al., 2003), which may be due to delayed gastrointestinal maturation (Decuypere and Bruggeman, 2007). 
Reports on the effects of skip-a-day feed removal on broiler performance have generally indicated a reduced feed intake, weight gain and lower market weight but contradict one another on effects on feed efficiency, mortality rate and abdominal fat deposition (Navidshad et al., 2006 and Khajali et al., 2007 and Benyi et al., 2011 and Ghazanfari et al., 2010). Depression of feed during hot hours of the day may be helpful to reduce the metabolic heat production (Silva De and Kalubowila, 2012). Organic acids are routinely included in diets for monogastric animals in Europe as preservative and acidifier, in order to replace antibiotics as growth promoters and prevent or control pathogens (Papatsiros et al., 2012). The acidifiers can modify the PH of both the feed and the animal`s digestive tract and can disrupt the normal cell function and protein synthesis of various gut microorganisms (Bonos et al., 2011). In addition, lowering the $\mathrm{pH}$ by organic acids improves nutrient absorption (Khana and Iqbalb, 2016). Several studies support the statement that dietary inclusions of acidifiers have improved growth performance in broiler chickens (Afsharmanesh and Pourreza, 2005, Atapattu and Nelligaswatta, 2005, Moghadam et al., 2006, Nezhad et al., 2007 and Abdel-Fattah et al., 2008). There is limited information on the response of broiler chickens to feed removal and using acetic acid for different number of days during the week. Finally, this study was to evaluate the effect of fasting period and addition of acetic acid in drinking water during a 2242days of age on growth performance, physiological measurements, carcass traits, intestinal microbial and economic efficiency under the Egyptian conditions of Cobb broiler.

\section{MATERIALS AND METHODS}

This study was carried out at the Poultry Experimental Station, Faculty of Agriculture, Al-Azhar University, Nasr City, Cairo, ARE This study was investigated the effect of feed withdrawal and addition of acetic acid in drinking water on growth performance, physiological measurements, carcass traits, carcass chemical composition, intestinal microbial and economic efficiency of Cobb broiler during the period from 22 to 42 days of age under Egyptian summer season condition. The experimental were carried out during the period from 20/6/2018 to 3/8/2018 in summer season. A total number of 270 one day old unsexed chicks were randomly distributed at one day of age into 6 experimental groups of three replicates containing 15 birds each. The control group (T1), T2, T3, T4, T5 and T6 were fed ad libitum, feed withdrawal (FW) 8 hours from (9.00AM-5.00PM) only, addition of acetic acid (6\%) in water only, (FW) 8 hours from (9.00AM-5.00PM) with addition of acetic acid (6\%) in water, addition of acetic acid $(8 \%)$ in water only and (FW) 8 hours from (9.00AM-5.00PM) with addition of acetic acid (8\%) in water, respectively.

\section{Chicks and management:}

The average temperature and relative humidity $(\mathrm{RH})$ of pens were daily measured and was recorded (36 $\mathrm{C}^{\mathrm{o}}$ at $12: 00 \mathrm{PM}-25 \mathrm{C}^{\mathrm{o}}$ at $12: 00 \mathrm{AM}$ and $52-70 \% \mathrm{RH}$ ) as an average during the experimental period from $20 / 6 / 2018$ to $3 / 8 / 2018$ in summer season. The pens were provided with continuous lighting, and naturally ventilated by windows adjustment. The pens were cleaned, fumigated with formaldehyde solution, and washed prior to the commencement of experimental of work. The pens were equipped with manual plastic feeders and drinkers of capacity had been used. Vaccination program was applied during the experimental period; the conditions of housing and management of birds for all groups were similar during the experimental period. All birds were healthy and clinically free from disease.

\section{Experimental diets:}

The experimental diets tabulated in Table (1). The requirements of chickens and composition of diets were calculated according to (Guide Cobb 500, 2018) and (NRC, 1994).

\section{Collected data and measurements growth performance:}

Average initial weight of chick one day old, live weight, weight gain, feed intake, feed efficiency and mortality were recorded weekly.

\section{Blood constituents:}

At the end of the experiment two birds from each pen were bled by cutting the carotid artery and blood was taken. Blood samples were taken at 6 weeks of age in tubes not contained anticoagulant for separate serum by centrifugation at $3000 \mathrm{rpm}$ for 15 minutes and stored at $(-20 \circ \mathrm{C})$ until analysis. Total protein, albumin, globulin, total cholesterol, low density lipoprotein (LDL), high density lipoprotein (HDL), total lipids, triglyceride, AST and Igg were determined using kits purchased from the agent of DiaSys Diagnostic System GmbH and measuring by spectrophotometer (Model 722 GRATING), following the same steps as described by manufactures. 
Table (1): Composition and calculated analysis of experimental diets of broiler chicks.

\begin{tabular}{|c|c|c|c|}
\hline \multirow[b]{2}{*}{ Ingredient } & \multicolumn{3}{|c|}{ Diets of broiler chick } \\
\hline & $\begin{array}{c}\text { Starter } \\
\text { (1-10 day) }\end{array}$ & $\begin{array}{c}\text { Grower } \\
\text { (11-22 day) }\end{array}$ & $\begin{array}{c}\text { Finisher } \\
(23-42 \text { day })\end{array}$ \\
\hline Ground yellow corn $8.8 \%$ & 60.25 & 63.225 & 64.265 \\
\hline Soybean meal $44 \%$ & 30.14 & 28.54 & 26.50 \\
\hline Corn gluten meal $60 \%$ & 4.23 & 1.90 & 1.80 \\
\hline Sunflower oil & 1.265 & 2.55 & 3.74 \\
\hline Dicalcium phosphate & 1.64 & 1.47 & 1.50 \\
\hline Limestone & 1.155 & 1.11 & 1.11 \\
\hline Premix ${ }^{*}$ & 0.30 & 0.30 & 0.30 \\
\hline Sodium Chloride $(\mathrm{NaCl})$ & 0.45 & 0.45 & 0.45 \\
\hline DL-methionine & 0.26 & 0.235 & 0.195 \\
\hline L-lysine- $\mathrm{HCl}$ & 0.28 & 0.21 & 0.14 \\
\hline Threonine & 0.03 & 0.01 & 0.00 \\
\hline Total $(\mathrm{Kg})$ & 100 & 100 & 100 \\
\hline \multicolumn{4}{|l|}{ Calculated analysis } \\
\hline Crude protein $\%$ & 22.02 & 20.00 & 19.01 \\
\hline ME. cal/Kg feed & 3007 & 3088 & 3168 \\
\hline Calcium\% & 0.90 & 0.84 & 0.84 \\
\hline Available P.\% & 0.45 & 0.42 & 0.42 \\
\hline Lysine\% & 1.33 & 1.19 & 1.07 \\
\hline Methionine $\%$ & 0.62 & 0.56 & 0.50 \\
\hline Methionine + Cysteine\% & 0.98 & 0.89 & 0.82 \\
\hline
\end{tabular}

\section{Body temperature and respiration rate:}

Within each treatment, 9 birds from each replicate were taken weekly for measuring skin temperatures $\left(S_{T}\right)$ and respiration rate $\left(R_{R}\right)$. These sets of measurements were taken in the same day every week in each replicate during the experiment time. The measurements were performed twice a day at $(12: 00 \mathrm{pm})$ and $(12: 00 \mathrm{am})$. Electronic thermometers with $0.1^{\circ} \mathrm{C}$ resolution were used at a time for measuring skin temperature by inserting the probe was put in contact with the skin under the right wing for one minute. Respiration rate $\left(R_{R}\right)$ was measured by counting the movements of body wall for one minute.

\section{Microbial population:}

Using a sterile glass or plastic container the intestine samples were collected under complete aseptic conditions. Sample containers were opened immediately before collection and close immediately after collection. The collected samples were placed in a cooler box with ice packs $\left(4-10^{\circ} \mathrm{C}\right)$ and immediately transported to the laboratory to be tested bacteriologically within a time limit. Both of total viable count was performed using pour plates technique and total coliform counts were determined using spread plate method described by (Quinn et al., 1994).

\section{Carcass characteristics:}

At the end of experiment, birds were deprived from the feed for 12 hours and individually weighed. A slaughter test was performed on 36 birds including 3 bird male and 3 females from each group, whose body weight was closest to the group mean. Birds were weighed before slaughter. Birds were allowed to bleed freely (2min) and reweighed to obtain blood weight. Feathers were plucked manually. Birds were then weighed to obtain feather weight. Carcass were eviscerated by hand and individually reweighed after the removal of head, neck, shanks, viscera, and giblets (liver, heart and gizzard) to obtain the dressed weight. The small intestine was individually measured in length for each carcass.

\section{Diets and carcass chemical composition:}

Determination of moisture, crude protein, ether extract, ash and nitrogen free extract (NFE by difference) were carried out in the diet and meat according to standard method of the association of official analytical chemists (AOAC, 2012). 


\section{Hamady et al.}

\section{Economics of production:}

At the end of the experimental period (42 days), the European Efficiency Factor (EEF) was calculated, by the following equation (Abbas et al., 2006).

$$
\mathrm{EPEF}=100 *[\mathrm{BW}(\mathrm{Kg}) * \text { viability }(\%)] /[\text { Age }(\text { days }) * \mathrm{FCR}]
$$

\section{Statistical analysis:}

Data analysis was performed using SPSS software program package (SPSS, 2001). All data were analyzed based on a completely randomized design using one-way ANOVA. All percentages were first transformed to arcsine to approximate normal distribution before ANOVA. Data were presented as means \pm standard error (Means \pm SE). When the treatment effect was significant at $p \leq 0.05$, Duncan's multiple range test was applied to identify significant differences among groups, (Duncan, 1955). All statements of significance are based on testing at $\mathrm{p} \leq 0.05$.

\section{RESUILTS AND DISCUSSIONS}

\section{Growth performance:}

Summarized in Table (2) is the average of initial weights at the start of the experiment (one day of age). Insignificant differences among the experimental groups indicating the random distribution of

Table (2): Effect of different treatments on growth performance of broiler chickens at 42 days of age (Means $\pm S$ E).

\begin{tabular}{|c|c|c|c|c|c|c|c|}
\hline \multirow[b]{2}{*}{ Item } & \multicolumn{7}{|c|}{ Treatment } \\
\hline & $\begin{array}{c}\text { (T1) } \\
\text { control }\end{array}$ & $\begin{array}{c}(\mathrm{T} 2) \\
(\mathrm{FW}) 8 \mathrm{hr} \\
\text { F8 }\end{array}$ & $\begin{array}{c}\text { (T3) } \\
\text { addition of } \\
\text { A.A 6\% } \\
\text { AD6 }\end{array}$ & $\begin{array}{c}\text { (T4) } \\
\text { addition of } \\
\text { A.A 6\%+ } \\
\text { (FW) 8hr } \\
\text { AD6F8 }\end{array}$ & $\begin{array}{l}\text { (T5) } \\
\text { addition of } \\
\text { A.A } 8 \% \\
\text { AD8 }\end{array}$ & $\begin{array}{c}\text { (T6) } \\
\text { addition of } \\
\text { A.A 8\%+ } \\
\text { (FW) 8hr } \\
\text { AD8F8 } \\
\end{array}$ & Sig. \\
\hline $\begin{array}{l}\text { Initial weight }(\mathrm{g}) \text { per } \\
\text { bird }\end{array}$ & & & & & & & N.S \\
\hline $\begin{array}{l}\text { Final live body } \\
\text { weight } \\
(\text { FLBW) (g) per bird }\end{array}$ & $\begin{array}{c}41.70 \\
\pm 0.07 \\
2138.12^{\mathrm{abc}} \\
\pm 30.28\end{array}$ & $\begin{array}{c}41.82 \\
\pm 0.09 \\
2094.48^{\mathrm{bc}} \\
\pm 23.99\end{array}$ & $\begin{array}{c}41.83 \\
\pm 0.1 \\
2158.37^{\mathrm{ab}} \\
\pm 22.19\end{array}$ & $\begin{array}{c}41.72 \\
\pm 0.12 \\
2132.43^{\mathrm{abc}} \\
\pm 19.56\end{array}$ & $\begin{array}{c}41.80 \\
\pm 0.07 \\
2186.16^{\mathrm{a}} \\
\pm 32.72\end{array}$ & $\begin{array}{c}41.84 \\
\pm 0.11 \\
2120.98^{\mathrm{abc}} \\
\pm 16.00\end{array}$ & $*$ \\
\hline $\begin{array}{l}\text { Live body weight } \\
\text { gain } \\
(\mathrm{LBWG})(\mathrm{g}) \text { per bird }\end{array}$ & $\begin{array}{c}2096.34^{\mathrm{abc}} \\
\pm 30.23\end{array}$ & $\begin{array}{l}2052.65^{\mathrm{bc}} \\
\pm 23.94\end{array}$ & $\begin{array}{c}2116.54^{\mathrm{ab}} \\
\pm 22.15\end{array}$ & $\begin{array}{c}2090.70^{\mathrm{abc}} \\
\pm 19.58\end{array}$ & $\begin{array}{l}2144.35^{\mathrm{a}} \\
\pm 32.67\end{array}$ & $\begin{array}{l}2079.14^{\mathrm{abc}} \\
\pm 16.00\end{array}$ & $*$ \\
\hline $\begin{array}{l}\text { Feed intake }(\mathrm{FI})(\mathrm{g}) \\
\text { per bird }\end{array}$ & $\begin{array}{l}3903.66^{\mathrm{a}} \\
\pm 6.48 \\
1.86^{\mathrm{a}} \\
\pm 0.006\end{array}$ & $\begin{array}{c}3675.00^{\mathrm{c}} \\
\pm 37.44 \\
1.79^{\mathrm{d}} \\
\pm 0.005\end{array}$ & $\begin{array}{c}3875.66^{\mathrm{a}} \\
\pm 15.81 \\
1.83^{\mathrm{b}} \\
\pm 0.005\end{array}$ & $\begin{array}{c}3763.00^{\mathrm{b}} \\
\pm 17.09 \\
1.80^{\mathrm{cd}} \\
\pm 0.005\end{array}$ & $\begin{array}{c}3880.33^{\mathrm{a}} \\
\pm 20.88 \\
1.81^{\mathrm{c}} \\
\pm 0.005\end{array}$ & $\begin{array}{c}3763.33^{\mathrm{b}} \\
\pm 12.44 \\
1.81^{\mathrm{c}} \\
\pm 0.005\end{array}$ & $*$ \\
\hline $\begin{array}{l}\text { Feed conversion ratio } \\
\text { (FCR) }\end{array}$ & $\begin{array}{l}8.89^{\mathrm{a}} \\
\pm 5.87\end{array}$ & $\begin{array}{l}0.00^{\mathrm{b}} \\
\pm 0.00\end{array}$ & $\begin{array}{l}0.00^{\mathrm{b}} \\
\pm 0.00\end{array}$ & $\begin{array}{l}0.00^{\mathrm{b}} \\
\pm 0.00\end{array}$ & $\begin{array}{l}2.22^{\mathrm{ab}} \\
\pm 2.22\end{array}$ & $\begin{array}{l}0.00^{\mathrm{b}} \\
\pm 0.00\end{array}$ & \\
\hline Mortality\% & & & & & & & \\
\hline
\end{tabular}

$a, b, c, d, e$ Means the same raw have the different superscript are significantly different $(P<0.05)$.

S.E: Meaning standard error. N.S: non-significant.

individuals among treatment groups at the experimental start. The highest $(\mathrm{P}<0.05)$ final weights and weights gain were recorded by the T5 followed by the other treatment groups (T3, T1, T4 and T6), which the differences between them were insignificant. Group $\mathrm{T} 2$ had the lowest $(\mathrm{P}<0.05)$ final weights and weights gain. Averages final weights for other groups lay between the higher and lowest final body weight groups. Improvement of weight gain was observed by addition of acetic acid, this may either be because organic acids lower chyme $\mathrm{pH}$ which increases pepsin activity. The peptides arising from pepsin 
proteolysis leads to release of hormones gastrin and cholecystokinin, which also helps to improve growth as a result to increase protein digestion (Gauthier, 2002). The highest $(\mathrm{P}<0.05)$ averages of daily feed intake (g/bird) were reported by T1, T5 and T3 followed in a significant $(\mathrm{P}<0.05)$ decreasing order by the T6, T4 and T2 groups, respectively. Group T2 had $(\mathrm{P}<0.05)$ the lowest daily feed intake records, due to the increase in the fasting time and mechanism of action for acetic acid which decreased cumulative feed intake (Adil et al., 2011). The averages of FCR for the groups T2 and T4 were improved significantly by increasing fasting time compared to the other groups. The mortality rate was the highest significantly for T1 followed by $\mathrm{T} 5$ compared to the other groups, this result is may due to many reasons like high temperatures or by accidents.

\section{Blood serum parameters:}

Tabulated in Table (3) is the total blood serum protein ( $\mathrm{g} / \mathrm{dl})$ and the records were within normal range and the higher numerical value was recorded by groups T5 (addition of $8 \%$ acetic acid). The lowest value was recorded by group T2 which suffered a fasting period ( 8 hours). Birds fed the other treatments showed intermediate values compared to the highest and the lowest value. This result is may be due to effect of fasting on blood constituents. Concerning total serum albumin levels (g/dl), T1 (control) achieved highest significant values compared to the other treatments. Total serum globulin levels were $(\mathrm{P}<0.05)$ the highly for $\mathrm{T} 1$ and $\mathrm{T} 5$ compared to T2 record. The lowest value and the differences between (T1 and T5) or (T2) and other treatments were insignificant. These results may be due to acetic acid which stimulates globulin production, where it considers a source of antibody production. An increase of globulin level in the serum is a good indicator of immune responses (Griminger and Scanes, 1986). The total serum cholesterol levels and LDL (mg/dl) were significantly increased for T1 (control) compared to T4 and T6 groups. HDL values were significantly decreased for T1compared to T6 and T5 groups. The dietary feed withdrawal and addition of acetic acid seemed to have significant effects on total serum cholesterol and LDL which were decreased by feed withdrawal and acetic acid addition. Acetic acid has an effect on microbial population and may be increased positive bacteria that depressed total serum cholesterol and LDL. May be lactic acid bacteria, like Lactobacillus, Bifidobacterium and Enterococcus, which have been suggested to lower cholesterol levels by different mechanisms (Bordoni et al., 2013). Furthermore, the highest total serum lipids $(\mathrm{P}<0.05)$ records were obtained by the groups $\mathrm{T} 1$ (control) followed by decreasing order by T3 and T5. The lowest values recorded by groups T2, T4 and T6. the highest values of total serum triglycerides $(\mathrm{P}<0.05)$ recorded by groups $\mathrm{T} 1$ (control) followed by decreasing order by $\mathrm{T} 5$ and $\mathrm{T} 3$. The lowest values $(\mathrm{P}<0.05)$ was obtained by the other groups. In general, fasting and addition of acetic acid have significant effects on total lipids and triglycerides where research showed that acetic acid inhibits the expression of lipogenic genes for acetyl-CoA carboxylase (ACC) and fatty acid synthase (FAS) via AMP-activated protein kinase (AMPK)/ carbohydrate responsive elementbinding protein, resulting reducing body fat deposition in rats (Yamashita et al., 2007). In addition, acetic acid downregulates ATP citrate lyase (ATP-CL), FAS, and ACC gene expression via sterol regulatory element-binding protein-1 (SREBP-1), thereby decreasing serum triglyceride (TG) levels in hyperlipidemia rats (Fushimi et al., 2006). Serum AST values were significantly decreased due to feed withdrawal or addition of acetic acid. The highest values recorded by groups T1 (control). The lowest values recoded by the T6. Acetic acid can reduce the inflammatory response by decreasing the expression of cytokines including interleukin 6 and tumor necrosis factor $\alpha$. Additionally, acetic acid alleviated the liver injury by decreased the level of aspartate aminotransferase. Therefore, the hypotheses that acetic acid could decrease the inflammatory response by increasing the expression of tripartite motif containing protein (TRIM) 40 (Yang et al., 2019).

The values of $\operatorname{Igg}(\mathrm{g} / \mathrm{L})$ was within normal range and the control group $\mathrm{T} 1$ was significantly higher value of Igg than the other groups. GroupT2 had a lower value of Igg and the differences among (T1 or T2) and the other treatments were insignificant. The withdrawal of feed or addition of acetic acid, Igg levels in the serum decreased as a result of increased immunity and may reduce inflammation (Lakos et al., 2008). 


\section{Hamady et al.}

Table (3): Effect of different treatments on blood serum of broiler chickens at 42 days of age $($ Means \pm S E).

\begin{tabular}{|c|c|c|c|c|c|c|c|}
\hline \multirow[b]{2}{*}{ Item } & \multicolumn{5}{|c|}{ Treatment } & \multirow[b]{2}{*}{$\begin{array}{c}\text { (T6) } \\
\text { addition of } \\
\text { A.A 8\%+ } \\
\text { (FW) 8hr } \\
\text { AD8F8 }\end{array}$} & \multirow[b]{2}{*}{ Sig } \\
\hline & $\begin{array}{c}\text { (T1) } \\
\text { control }\end{array}$ & $\begin{array}{c}(\mathrm{T} 2) \\
(\mathrm{FW}) 8 \mathrm{hr} \\
\text { F8 }\end{array}$ & $\begin{array}{c}\text { (T3) } \\
\text { addition of } \\
\text { A.A 6\% } \\
\text { AD6 }\end{array}$ & $\begin{array}{c}\text { (T4) } \\
\text { addition of } \\
\text { A.A 6\%+ } \\
\text { (FW) 8hr } \\
\text { AD6F8 }\end{array}$ & $\begin{array}{c}\text { (T5) } \\
\text { addition of } \\
\text { A.A } 8 \% \\
\text { AD8 }\end{array}$ & & \\
\hline $\begin{array}{l}\text { Total protein }(\mathrm{g} \\
\text { /dl) }\end{array}$ & $\begin{array}{c}5.75 \\
\pm 0.47\end{array}$ & $\begin{array}{c}4.95 \\
\pm 0.14\end{array}$ & $\begin{array}{c}5.48 \\
\pm 0.23\end{array}$ & $\begin{array}{c}5.09 \\
\pm 0.35\end{array}$ & $\begin{array}{c}5.77 \\
\pm 0.09\end{array}$ & $5.01 \pm 0.10$ & N.S \\
\hline Albumin (g/dl) & $\begin{array}{l}3.28^{\text {a }} \\
\pm 0.35\end{array}$ & $\begin{array}{l}2.51^{b} \\
\pm 0.06\end{array}$ & $\begin{array}{l}2.74^{\mathrm{b}} \\
\pm 0.12\end{array}$ & $\begin{array}{l}2.40^{\mathrm{b}} \\
\pm 0.08\end{array}$ & $\begin{array}{l}2.75^{b} \\
\pm 0.04\end{array}$ & $\begin{array}{l}2.77^{b} \\
\pm 0.19\end{array}$ & $*$ \\
\hline Globulin (g/dl) & $\begin{array}{l}2.29^{a} \\
\pm 0.34\end{array}$ & $\begin{array}{l}1.51^{\mathrm{b}} \\
\pm 0.06\end{array}$ & $\begin{array}{l}2.13^{\mathrm{ab}} \\
\pm 0.18\end{array}$ & $\begin{array}{l}2.00^{\mathrm{ab}} \\
\pm 0.21\end{array}$ & $\begin{array}{l}2.20^{\mathrm{a}} \\
\pm 0.20\end{array}$ & $\begin{array}{l}2.02^{\mathrm{ab}} \\
\pm 0.19\end{array}$ & $*$ \\
\hline $\begin{array}{l}\text { Total cholesterol } \\
(\mathrm{mg} / \mathrm{dl})\end{array}$ & $\begin{array}{c}172.00^{\mathrm{a}} \\
\pm 9.23\end{array}$ & $\begin{array}{l}159.50^{\mathrm{ab}} \\
\pm 12.99\end{array}$ & $\begin{array}{c}163.66^{\mathrm{ab}} \\
\pm 9.13\end{array}$ & $\begin{array}{c}141.00^{\mathrm{b}} \\
\pm 4.61\end{array}$ & $\begin{array}{c}162.66^{\mathrm{ab}} \\
\pm 8.96\end{array}$ & $\begin{array}{c}140.66^{\mathrm{b}} \\
\pm 4.80\end{array}$ & $*$ \\
\hline $\begin{array}{l}\text { High density } \\
\text { lipoprotein } \\
(\mathrm{HDL})(\mathrm{mg} / \mathrm{dl})\end{array}$ & $\begin{array}{l}52.83 \mathrm{c} \\
\pm 3.72\end{array}$ & $\begin{array}{c}57.66^{b c} \\
\pm 1.45\end{array}$ & $\begin{array}{l}58.66^{\mathrm{bc}} \\
\pm 2.02\end{array}$ & $\begin{array}{c}60.00^{\mathrm{bc}} \\
\pm 3.78\end{array}$ & $\begin{array}{c}64.00^{\mathrm{ab}} \\
\pm 1.15\end{array}$ & $\begin{array}{l}71.66^{\mathrm{a}} \\
\pm 1.76\end{array}$ & $*$ \\
\hline $\begin{array}{l}\text { Low density } \\
\text { lipoprotein (LDL) } \\
(\mathrm{mg} / \mathrm{dl})\end{array}$ & $\begin{array}{l}83.96^{\mathrm{a}} \\
\pm 7.80\end{array}$ & $\begin{array}{l}70.43^{\mathrm{ab}} \\
\pm 12.99\end{array}$ & $\begin{array}{l}72.50^{\mathrm{ab}} \\
\pm 7.33\end{array}$ & $\begin{array}{l}50.80^{\mathrm{bc}} \\
\pm 3.01\end{array}$ & $\begin{array}{c}65.80^{\mathrm{ab}} \\
\pm 9.40\end{array}$ & $\begin{array}{l}37.40^{c} \\
\pm 4.015\end{array}$ & $*$ \\
\hline $\begin{array}{l}\text { Total lipids (g } \\
\text { /dl) }\end{array}$ & $\begin{array}{c}658.85^{\mathrm{a}} \\
\pm 6.55\end{array}$ & $\begin{array}{c}586.30^{\text {bcd }} \\
\pm 38.39\end{array}$ & $\begin{array}{c}642.43^{\mathrm{ab}} \\
\pm 7.68\end{array}$ & $\begin{array}{l}558.41^{\mathrm{cd}} \\
\pm 5.83\end{array}$ & $\begin{array}{l}613.25^{\mathrm{abc}} \\
\pm 31.66\end{array}$ & $\begin{array}{c}550.85^{\mathrm{d}} \\
\pm 4.24\end{array}$ & $*$ \\
\hline $\begin{array}{l}\text { Triglycerides } \\
(\mathrm{mg} / \mathrm{dl})\end{array}$ & $\begin{array}{c}176.00^{\mathrm{a}} \\
\pm 3.46\end{array}$ & $\begin{array}{l}157.00^{\mathrm{b}} \\
\pm 5.56\end{array}$ & $\begin{array}{c}162.50^{\mathrm{ab}} \\
\pm 3.75\end{array}$ & $\begin{array}{c}151.00^{\mathrm{b}} \\
\pm 9.81\end{array}$ & $\begin{array}{c}164.33^{\mathrm{ab}} \\
\pm 3.84\end{array}$ & $\begin{array}{c}158.00^{\mathrm{b}} \\
\pm 5.13\end{array}$ & $*$ \\
\hline AST (U/L) & $\begin{array}{c}43.33^{\mathrm{a}} \\
\pm 1.76\end{array}$ & $\begin{array}{c}41.66^{\mathrm{ab}} \\
\pm 1.20\end{array}$ & $\begin{array}{c}38.33 \mathrm{bc} \\
\pm 1.76\end{array}$ & $\begin{array}{c}36.66^{\mathrm{bc}} \\
\pm 1.76\end{array}$ & $\begin{array}{c}37.33^{b c} \\
\pm 1.45\end{array}$ & $\begin{array}{l}35.66^{\mathrm{c}} \\
\pm 1.45\end{array}$ & $*$ \\
\hline $\operatorname{Igg}(g / L)$ & $\begin{array}{l}15.55^{\mathrm{a}} \\
\pm 0.25 \\
\end{array}$ & $\begin{array}{l}12.80^{b} \\
\pm 0.46 \\
\end{array}$ & $\begin{array}{c}15.15^{a b} \\
\pm 0.66 \\
\end{array}$ & $\begin{array}{c}13.26^{a b} \\
\pm 0.70 \\
\end{array}$ & $\begin{array}{l}15.2^{\text {ab }} \\
\pm 0.23 \\
\end{array}$ & $\begin{array}{c}13.40^{\mathrm{ab}} \\
\pm 1.93 \\
\end{array}$ & $*$ \\
\hline
\end{tabular}

a,b,c,d,e Means the same raw have the different superscript are significantly different $(P<0.05)$.

S.E: Meaning standard error. N.S: non-significant.

\section{Temperature and respiration:}

Results of Tables (4 and 5) indicated that no significant difference was observed among groups in terms of skin temperature and respiration rate during 1, 2 and 3 weeks of age. In 4, 5 and 6 weeks of age, skin temperature was significantly increased for control groups (T1) compared to the groups of feed withdrawal and the differences between (T1) and groups treated with acetic acid were insignificant. These results may be due to increased heat load for control group (Whitehead and Keller, 2003).

\section{Carcass characteristics:}

The analysis of variance in Table (6) showed that the gizzard, liver and heart weights were insignificantly affected by treatments. Significant changes were observed in dressing carcass and abdominal fat weight $(\mathrm{g})$. Dressing carcass of T5 birds was significantly the highest compared to T2 birds and the differences among (T5 or T2) with the other treatments were insignificant. The abdominal fat weight was $(\mathrm{p}<0.05)$ the higher for birds fed ad libitum (T1) compared to the other groups. These results may be due to below the starved condition, fatty acids derived from adipose tissue are oxidized by Boxidation to form ketone bodies and acetate as the final products (Yamashita et al., 2001). Length of small intestine $(\mathrm{cm})$ was significantly decreased by increased time of fasting. Addition of acetic acid increased $(p<0.05)$ the length of intestine. These results may be due to the fact that short chain fatty acids can stimulates gut epithelial cell proliferation, thus increase intestinal tissue weight, which will result in changes of mucosal morphology (LeBlay et al., 2000 and Fukunaga et al., 2003). 
Table (4): Effect of different treatments on skin temperature $\mathrm{C}^{\circ}$ during 24 hours of broiler chickens at 42 days of age (Means $\pm S \mathrm{E}$ ).

\begin{tabular}{|c|c|c|c|c|c|c|c|}
\hline \multirow[b]{2}{*}{ Item } & \multicolumn{5}{|c|}{ Treatment } & \multirow[b]{2}{*}{$\begin{array}{c}\text { (T6) } \\
\text { addition } \\
\text { of A.A } \\
8 \%+ \\
\text { (FW) } \\
8 \mathrm{hr} \\
\text { AD8F8 }\end{array}$} & \multirow[b]{2}{*}{ Sig. } \\
\hline & $\begin{array}{c}\text { (T1) } \\
\text { control }\end{array}$ & $\begin{array}{c}\text { (T2) } \\
(\mathrm{FW}) \\
\text { 8hr F8 }\end{array}$ & $\begin{array}{c}\text { (T3) } \\
\text { addition } \\
\text { of A.A } \\
6 \% \text { AD6 }\end{array}$ & $\begin{array}{c}\text { (T4) } \\
\text { addition } \\
\text { of A.A } \\
6 \%+ \\
(\mathrm{FW}) \\
8 \mathrm{hr} \\
\text { AD6F8 }\end{array}$ & $\begin{array}{c}\text { (T5) } \\
\text { addition } \\
\text { of A.A } \\
8 \% \text { AD8 }\end{array}$ & & \\
\hline First week & $\begin{array}{l}52.00 \\
\pm 2.51\end{array}$ & $\begin{array}{l}51.32 \\
\pm 1.64\end{array}$ & $\begin{array}{l}51.94 \\
\pm 2.10\end{array}$ & $\begin{array}{l}50.83 \\
\pm 2.31\end{array}$ & $\begin{array}{l}50.22 \\
\pm 1.78\end{array}$ & $\begin{array}{l}50.88 \\
\pm 2.42\end{array}$ & N. S \\
\hline Second week & $\begin{array}{l}57.00 \\
\pm 2.51\end{array}$ & $\begin{array}{l}56.32 \\
\pm 1.64\end{array}$ & $\begin{array}{l}56.94 \\
\pm 2.10\end{array}$ & $\begin{array}{l}55.83 \\
\pm 2.31\end{array}$ & $\begin{array}{l}55.22 \\
\pm 1.79\end{array}$ & $\begin{array}{l}55.88 \\
\pm 2.42\end{array}$ & N. S \\
\hline Third week & $\begin{array}{l}65.66 \\
\pm 2.49\end{array}$ & $\begin{array}{l}67.16 \\
\pm 2.78\end{array}$ & $\begin{array}{l}64.61 \\
\pm 2.09\end{array}$ & $\begin{array}{l}65.55 \\
\pm 2.62\end{array}$ & $\begin{array}{l}64.94 \\
\pm 2.53\end{array}$ & $\begin{array}{l}66.44 \\
\pm 3.30\end{array}$ & N. S \\
\hline Forth week & $\begin{array}{l}68.97^{\mathrm{a}} \\
\pm 1.95\end{array}$ & $\begin{array}{c}59.05^{\mathrm{bc}} \\
\pm 1.76\end{array}$ & $\begin{array}{c}63.88^{a b} \\
\pm 2.06\end{array}$ & $\begin{array}{c}55.94^{\mathrm{cd}} \\
\pm 1.77\end{array}$ & $\begin{array}{l}61.61^{\mathrm{b}} \\
\pm 1.41\end{array}$ & $\begin{array}{l}50.22^{\mathrm{e}} \\
\pm 2.10\end{array}$ & $*$ \\
\hline Fifth week & $\begin{array}{l}81.38^{\mathrm{a}} \\
\pm 2.66\end{array}$ & $\begin{array}{c}66.33^{b c} \\
\pm 2.60\end{array}$ & $\begin{array}{l}73.11^{\mathrm{b}} \\
\pm 3.03\end{array}$ & $\begin{array}{c}60.66^{\mathrm{cd}} \\
\pm 2.23\end{array}$ & $\begin{array}{c}68.38^{b c} \\
\pm 2.55\end{array}$ & $\begin{array}{l}57.05^{\mathrm{d}} \\
\pm 2.30\end{array}$ & $*$ \\
\hline Sixth week & $\begin{array}{l}79.50^{\mathrm{a}} \\
\pm 2.75\end{array}$ & $\begin{array}{c}67.94^{\mathrm{bc}} \\
\pm 2.36\end{array}$ & $\begin{array}{l}76.33^{\mathrm{a}} \\
\pm 3.23\end{array}$ & $\begin{array}{l}62.27^{c} \\
\pm 2.65\end{array}$ & $\begin{array}{c}71.83^{\mathrm{ab}} \\
\pm 2.64\end{array}$ & $\begin{array}{l}60.80^{c} \\
\pm 2.93\end{array}$ & $*$ \\
\hline
\end{tabular}

a,b,c,d,e Means the same raw have the different superscript are significantly different $(P<0.05)$.

S.E: Meaning standard error. N.S: non-significant.

Table (5): Effect of different treatments on respiration rate during 24 hours of broiler chickens at 42 days of age (Means $\pm S E$ ).

\begin{tabular}{|c|c|c|c|c|c|c|c|}
\hline \multirow[b]{2}{*}{ Item } & \multicolumn{5}{|c|}{ Treatment } & \multirow[b]{2}{*}{$\begin{array}{c}\text { (T6) } \\
\text { addition } \\
\text { of A.A } \\
8 \%+ \\
\text { (FW) } \\
8 \mathrm{hr} \\
\text { AD8F8 }\end{array}$} & \multirow[b]{2}{*}{ Sig. } \\
\hline & $\begin{array}{c}\text { (T1) } \\
\text { control }\end{array}$ & $\begin{array}{c}\text { (T2) } \\
(\mathrm{FW}) \\
\text { 8hr F8 }\end{array}$ & $\begin{array}{c}\text { (T3) } \\
\text { addition } \\
\text { of A.A } \\
6 \% \text { AD6 }\end{array}$ & $\begin{array}{c}\text { (T4) } \\
\text { addition } \\
\text { of A.A } \\
6 \%+ \\
(\mathrm{FW}) \\
8 \mathrm{hr} \\
\text { AD6F8 }\end{array}$ & $\begin{array}{c}\text { (T5) } \\
\text { addition } \\
\text { of A.A } \\
8 \% \text { AD8 }\end{array}$ & & \\
\hline First week & $\begin{array}{l}52.00 \\
\pm 2.51\end{array}$ & $\begin{array}{l}51.32 \\
\pm 1.64\end{array}$ & $\begin{array}{l}51.94 \\
\pm 2.10\end{array}$ & $\begin{array}{l}50.83 \\
\pm 2.31\end{array}$ & $\begin{array}{l}50.22 \\
\pm 1.78\end{array}$ & $\begin{array}{l}50.88 \\
\pm 2.42\end{array}$ & N.S \\
\hline Second week & $\begin{array}{l}57.00 \\
\pm 2.51\end{array}$ & $\begin{array}{l}56.32 \\
\pm 1.64\end{array}$ & $\begin{array}{l}56.94 \\
\pm 2.10\end{array}$ & $\begin{array}{l}55.83 \\
\pm 2.31\end{array}$ & $\begin{array}{l}55.22 \\
\pm 1.79\end{array}$ & $\begin{array}{l}55.88 \\
\pm 2.42\end{array}$ & N.S \\
\hline Third week & $\begin{array}{l}65.66 \\
\pm 2.49\end{array}$ & $\begin{array}{l}67.16 \\
\pm 2.78\end{array}$ & $\begin{array}{l}64.61 \\
\pm 2.09\end{array}$ & $\begin{array}{l}65.55 \\
\pm 2.62\end{array}$ & $\begin{array}{l}64.94 \\
\pm 2.53\end{array}$ & $\begin{array}{l}66.44 \\
\pm 3.30\end{array}$ & N.S \\
\hline Forth week & $\begin{array}{l}68.97^{\mathrm{a}} \\
\pm 1.95\end{array}$ & $\begin{array}{c}59.05^{\mathrm{bc}} \\
\pm 1.76\end{array}$ & $\begin{array}{c}63.88 \mathrm{ab} \\
\pm 2.06\end{array}$ & $\begin{array}{c}55.94^{\mathrm{cd}} \\
\pm 1.77\end{array}$ & $\begin{array}{l}61.61^{\mathrm{b}} \\
\pm 1.41\end{array}$ & $\begin{array}{l}50.22^{\mathrm{e}} \\
\pm 2.10\end{array}$ & $*$ \\
\hline Fifth week & $\begin{array}{l}81.38^{a} \\
\pm 2.66\end{array}$ & $\begin{array}{c}66.33^{\mathrm{bc}} \\
\pm 2.60\end{array}$ & $\begin{array}{l}73.11^{\mathrm{b}} \\
\pm 3.03\end{array}$ & $\begin{array}{c}60.66^{\mathrm{cd}} \\
\pm 2.23\end{array}$ & $\begin{array}{c}68.38^{b c} \\
\pm 2.55\end{array}$ & $\begin{array}{l}57.05^{\mathrm{d}} \\
\pm 2.30\end{array}$ & $*$ \\
\hline Sixth week & $\begin{array}{l}79.50^{\mathrm{a}} \\
\pm 2.75\end{array}$ & $\begin{array}{c}67.94^{\mathrm{bc}} \\
\pm 2.36\end{array}$ & $\begin{array}{l}76.33^{\mathrm{a}} \\
\pm 3.23\end{array}$ & $\begin{array}{l}62.27^{\mathrm{c}} \\
\pm 2.65\end{array}$ & $\begin{array}{c}71.83^{\mathrm{ab}} \\
\pm 2.64\end{array}$ & $\begin{array}{l}60.80^{c} \\
\pm 2.93\end{array}$ & $*$ \\
\hline
\end{tabular}

$a, b, c, d, e$ Means the same raw have the different superscript are significantly different $(P<0.05)$.

S.E: Meaning standard error. N.S: non-significant. 
Table (6): Effect of different treatments on carcass characteristics of broiler chickens at 42 days of age (Means $\pm \mathrm{S} \mathrm{E})$.

\begin{tabular}{|c|c|c|c|c|c|c|c|}
\hline \multirow[b]{2}{*}{ Item } & \multicolumn{7}{|c|}{ Treatment } \\
\hline & $\begin{array}{c}\text { (T1) } \\
\text { control }\end{array}$ & $\begin{array}{c}(\mathrm{T} 2)(\mathrm{FW}) \\
\text { 8hr F8 }\end{array}$ & $\begin{array}{c}\text { (T3) } \\
\text { addition of } \\
\text { A.A 6\% } \\
\text { AD6 }\end{array}$ & $\begin{array}{c}\text { (T4) } \\
\text { addition of } \\
\text { A.A 6\%+ } \\
\text { (FW) 8hr } \\
\text { AD6F8 }\end{array}$ & $\begin{array}{c}\text { (T5) } \\
\text { addition of } \\
\text { A.A } 8 \% \\
\text { AD8 }\end{array}$ & $\begin{array}{c}\text { (T6) } \\
\text { addition of } \\
\text { A.A 8\%+ } \\
\text { (FW) 8hr } \\
\text { AD8F8 }\end{array}$ & Sig. \\
\hline \multirow[t]{2}{*}{ Dressing carcass $(\mathrm{g})$} & $1452.46^{\mathrm{ab}}$ & $1398.06^{\mathrm{b}}$ & $1463.44^{\mathrm{ab}}$ & $1406.82^{\mathrm{ab}}$ & $1477.60^{\mathrm{a}}$ & $1403.13^{\mathrm{ab}}$ & \multirow{2}{*}{$*$} \\
\hline & \pm 13.40 & \pm 23.48 & \pm 43.78 & \pm 20.67 & \pm 14.50 & \pm 14.66 & \\
\hline \multirow{2}{*}{ Gizzard (g) } & 37.00 & 35.33 & 38.33 & 36.66 & 40.00 & 35.66 & \multirow{2}{*}{ N.S } \\
\hline & \pm 1.0 & \pm 2.33 & \pm 1.20 & \pm 1.20 & \pm 2.30 & \pm 1.85 & \\
\hline \multirow[t]{2}{*}{ Liver (g) } & 52.33 & 51.60 & 51.53 & 51.66 & 52.66 & 52.00 & \multirow{2}{*}{ N.S } \\
\hline & \pm 1.45 & \pm 3.33 & \pm 2.14 & \pm 2.96 & \pm 4.48 & \pm 4.61 & \\
\hline \multirow{2}{*}{ Heart $(\mathrm{g})$} & 9.30 & 9.13 & 8.26 & 9.06 & 8.26 & 8.96 & \multirow{2}{*}{ N.S } \\
\hline & \pm 0.35 & \pm 0.03 & \pm 0.33 & \pm 0.63 & \pm 0.23 & \pm 0.48 & \\
\hline \multirow[t]{2}{*}{ Abdominal fat $(\mathrm{g})$} & $47.00^{\mathrm{a}}$ & $32.00^{b c}$ & $36.33^{\mathrm{b}}$ & $30.00^{c}$ & $35.00^{b}$ & $29.33^{c}$ & \\
\hline & \pm 0.57 & \pm 1.00 & \pm 2.60 & \pm 2.64 & \pm 0.57 & \pm 0.88 & \\
\hline \multirow{2}{*}{$\begin{array}{l}\text { Length of small } \\
\text { intestine }(\mathrm{cm})\end{array}$} & $162.33^{\mathrm{abc}}$ & $160.33^{c}$ & $166.33^{\mathrm{ab}}$ & $163.33^{\mathrm{abc}}$ & $168.00^{\mathrm{a}}$ & $164.66^{\mathrm{abc}}$ & \multirow{2}{*}{$*$} \\
\hline & \pm 1.45 & \pm 1.45 & \pm 1.45 & \pm 1.45 & \pm 2.00 & \pm 1.76 & \\
\hline
\end{tabular}

$a, b, c, d, e$ Means the same raw have the different superscript are significantly different $(P<0.05)$.

S.E: Meaning standard error. N.S: non-significant.

\section{Chemical body composition:}

In Table (7) Moisture, dry matter, protein, EE and NFE percentages were not affected by treatments. While ash was significantly affected. The lowest values recorded by $\mathrm{T} 1$ and $\mathrm{T} 3$ compared to the other treatments which recorded the highest values. These results may be due to calcium consider component of ash in muscle, it is known that dietary calcium is transported across the epithelial membrane of the small intestinal by passive diffusion and active transport (Bronner 1987). Thus, there are two possible explanations for the drinking acetic acid increasing in calcium absorption. First, the ionized calcium concentration in the intestine is increased due to the acetic acid increases passive diffusion, also stimulates active calcium absorption (Heaney et al., 1990).

\section{Microbial population:}

The total bacteria account of intestine was significantly $(\mathrm{P}<0.05)$ higher in birds that drank acetic acid as compared with the control and feed withdrawal groups. Coliform bacteria account was significantly $(\mathrm{P}<0.05)$ lower in birds that drank acetic acid (Table 8). These results may be due to organic acids have an antimicrobial effect because they diffuse through the bacterial cell membrane, dissociate into anions and protons, and eventually disturb the intracellular electron-balance (Luckstadt, 2007 and Strauss and Hayler, 2001). These results are in line with Philipsen, (2006) who revealed that addition of organic acid to the drinking water helps to reduce the level of pathogens in the water and to regulate gut microflora.

\section{Economics of production:}

The highest value of European production efficiency factor (EPEF) was recorded for T4. EPEF were significantly increased for all treatments except the control group, may be due to increasing mortality in the control (T1). 
Table (7): Effect of different treatments on chemical body composition of broiler chickens at 42 days of age (Means $\pm S \mathrm{E})$.

\begin{tabular}{|c|c|c|c|c|c|c|c|}
\hline \multirow[b]{2}{*}{ Item } & \multicolumn{7}{|c|}{ Treatment } \\
\hline & $\begin{array}{l}\text { (T1) } \\
\text { control }\end{array}$ & $\begin{array}{c}\text { (T2) } \\
(\mathrm{FW}) \\
\text { 8hr F8 }\end{array}$ & $\begin{array}{c}(\mathrm{T} 3) \\
\text { addition } \\
\text { of A.A } \\
6 \% \text { AD6 }\end{array}$ & $\begin{array}{c}\text { (T4) } \\
\text { addition of } \\
\text { A.A 6\%+ } \\
(\mathrm{FW}) \\
\text { 8hr AD6F8 }\end{array}$ & $\begin{array}{c}\text { (T5) } \\
\text { addition } \\
\text { of A.A } \\
8 \% \text { AD8 }\end{array}$ & $\begin{array}{c}\text { (T6) } \\
\text { addition of } \\
\text { A.A } 8 \%+ \\
(\text { FW }) \\
\text { 8hr AD8F8 }\end{array}$ & Sig. \\
\hline Moisture \% & $\begin{array}{l}69.04 \\
\pm 0.13\end{array}$ & $\begin{array}{l}68.10 \\
\pm 0.17\end{array}$ & $\begin{array}{l}68.70 \\
\pm 0.13\end{array}$ & $\begin{array}{l}68.64 \\
\pm 1.45\end{array}$ & $\begin{array}{l}68.37 \\
\pm 0.36\end{array}$ & $\begin{array}{l}68.59 \\
\pm 1.09\end{array}$ & N.S \\
\hline Dry matter \% & $\begin{array}{l}30.96 \\
\pm 0.13\end{array}$ & $\begin{array}{c}31.89 \\
b \pm 0.17\end{array}$ & $\begin{array}{l}31.29 \\
\pm 0.13\end{array}$ & $31.35 \pm 1.45$ & $\begin{array}{l}31.63 \\
\pm 0.36\end{array}$ & $31.40 \pm 1.09$ & N.S \\
\hline Protein \% & $\begin{array}{l}64.04 \\
\pm 1.29\end{array}$ & $\begin{array}{l}65.27 \\
\pm 1.43\end{array}$ & $\begin{array}{l}63.55 \\
\pm 0.94\end{array}$ & $66.30 \pm 1.41$ & $\begin{array}{l}64.14 \\
\pm 1.05\end{array}$ & $64.52 \pm 1.51$ & N.S \\
\hline Ether extract EE\% & $\begin{array}{l}30.71 \\
\pm 1.44\end{array}$ & $\begin{array}{l}28.16 \\
\pm 1.49\end{array}$ & $\begin{array}{l}30.99 \\
\pm 0.77\end{array}$ & $\begin{array}{l}27.46 \\
\pm 1.13\end{array}$ & $\begin{array}{l}30.20 \\
\pm 1.03\end{array}$ & $\begin{array}{l}29.38 \\
\pm 1.55\end{array}$ & N.S \\
\hline Ash\% & $\begin{array}{l}5.18^{c} \\
\pm 0.11\end{array}$ & $\begin{array}{l}5.91^{\mathrm{a}} \\
\pm 0.03\end{array}$ & $\begin{array}{l}5.40^{\mathrm{bc}} \\
\pm 0.22\end{array}$ & $\begin{array}{l}5.87^{\mathrm{a}} \\
\pm 0.04\end{array}$ & $\begin{array}{l}5.63^{\mathrm{ab}} \\
\pm 0.05\end{array}$ & $\begin{array}{l}5.89^{\mathrm{a}} \\
\pm 0.01\end{array}$ & $*$ \\
\hline NFE \% & $\begin{array}{c}0.05 \\
\pm 0.02 \\
\end{array}$ & $\begin{array}{c}0.19 \\
\pm 0.11 \\
\end{array}$ & $\begin{array}{c}0.05 \\
\pm 0.003 \\
\end{array}$ & $\begin{array}{c}0.36 \\
\pm 0.32 \\
\end{array}$ & $\begin{array}{c}0.02 \\
\pm 0.003 \\
\end{array}$ & $\begin{array}{r}0.20 \\
\pm 0.01 \\
\end{array}$ & N.S \\
\hline
\end{tabular}

$a, b, c, d$,e Means the same raw have the different superscript are significantly different $(P<0.05)$.

S.E: Meaning standard error. N.S: non-significant.

Table (8): Effect of different treatments on intestine microbial population ( $\mathrm{Log} 10 \mathrm{cfu}$ ) of broiler Chickens at 42 days of age (Means \pm S E).

\begin{tabular}{|c|c|c|c|c|c|c|c|}
\hline \multirow[b]{2}{*}{ Item } & \multicolumn{7}{|c|}{ Treatment } \\
\hline & $\begin{array}{c}\text { (T1) } \\
\text { control }\end{array}$ & $\begin{array}{c}\text { (T2) } \\
(\mathrm{FW}) \\
\text { 8hr F8 }\end{array}$ & $\begin{array}{c}\text { (T3) } \\
\text { addition } \\
\text { of A.A } \\
6 \% \text { AD6 }\end{array}$ & $\begin{array}{c}\text { (T4) addition } \\
\text { of A.A } 6 \%+ \\
(\mathrm{FW}) \\
\text { 8hr AD6F8 }\end{array}$ & $\begin{array}{c}\text { (T5) } \\
\text { addition of } \\
\text { A.A } 8 \% \\
\text { AD8 }\end{array}$ & $\begin{array}{c}\text { (T6) addition } \\
\text { of A.A } 8 \%+ \\
(\mathrm{FW}) \\
\text { 8hr AD8F8 }\end{array}$ & Sig. \\
\hline \multirow{2}{*}{$\begin{array}{l}\text { Total bacteria } \\
\text { account }\end{array}$} & $8.65^{b}$ & $8.330^{c}$ & $9.21^{\mathrm{a}}$ & $9.07^{\mathrm{a}}$ & $9.29^{a}$ & $9.12^{\mathrm{a}}$ & \multirow{2}{*}{$*$} \\
\hline & \pm 0.04 & \pm 0.01 & \pm 0.03 & \pm 0.02 & \pm 0.16 & \pm 0.09 & \\
\hline \multirow{2}{*}{$\begin{array}{l}\text { Coliform bacteria } \\
\text { account }\end{array}$} & $7.66^{\mathrm{a}}$ & $7.12^{b}$ & $6.21^{c}$ & $5.36^{\mathrm{e}}$ & $6.04^{\mathrm{d}}$ & $5.33^{\mathrm{e}}$ & \multirow{2}{*}{$*$} \\
\hline & \pm 0.01 & \pm 0.04 & \pm 0.06 & \pm 0.07 & \pm 0.03 & \pm 0.02 & \\
\hline
\end{tabular}

$a, b, c, d, e$ Means the same raw have the different superscript are significantly different $(P<0.05)$.

S.E: Meaning standard error. N.S: non-significant.

Table (9): Effect of different treatments on (EPEF*) of broiler chickens at 42 days of age (Means \pm S E).

\begin{tabular}{|c|c|c|c|c|c|c|c|}
\hline Item & $\begin{array}{c}\text { (T1) } \\
\text { control }\end{array}$ & $\begin{array}{c}\text { (T2) } \\
(\mathrm{FW}) \\
\text { 8hr F8 }\end{array}$ & $\begin{array}{c}\text { (T3) } \\
\text { addition } \\
\text { of A.A } \\
6 \% \text { AD6 }\end{array}$ & $\begin{array}{c}\text { (T4) } \\
\text { addition of } \\
\text { A.A } 6 \%+ \\
\text { (FW) } \\
\text { 8hr AD6F8 }\end{array}$ & $\begin{array}{c}\text { (T5) } \\
\text { addition } \\
\text { of A.A } \\
8 \% \text { AD8 }\end{array}$ & $\begin{array}{c}\text { (T6) } \\
\text { addition of } \\
\text { A.A } 8 \%+ \\
\text { (FW) } \\
\text { 8hr AD8F8 }\end{array}$ & Sig. \\
\hline $\begin{array}{l}\text { Feed conversion } \\
\text { ratio }(\mathrm{FCR})\end{array}$ & $\begin{array}{c}1.86 \\
\pm 0.006\end{array}$ & $\begin{aligned} & 1.79 \\
\pm & 0.005\end{aligned}$ & $\begin{array}{c}1.83 \\
\pm 0.005\end{array}$ & $\begin{array}{c}1.80 \\
\pm 0.005\end{array}$ & $\begin{array}{c}1.81 \\
\pm 0.005\end{array}$ & $\begin{array}{c}1.81 \\
\pm 0.005\end{array}$ & - \\
\hline $\begin{array}{l}\text { Final live body } \\
\text { weight }(\mathrm{kg})\end{array}$ & $\begin{array}{l}2.096 \\
\pm 0.01\end{array}$ & $\begin{array}{l}2.053 \\
\pm 0.01\end{array}$ & $\begin{array}{l}2.116 \\
\pm 0.01\end{array}$ & $2.090 \pm 0.01$ & $\begin{array}{l}2.146 \\
\pm 0.01\end{array}$ & $\begin{array}{c}2.080 \\
\pm 0.001\end{array}$ & - \\
\hline Livability $\%$ & $\begin{array}{l}91.11 \\
\pm 5.87\end{array}$ & $\begin{array}{l}100.00 \\
\pm 0.00\end{array}$ & $\begin{array}{l}100.00 \\
\pm 0.00\end{array}$ & $\begin{array}{l}100.00 \\
\pm 0.00\end{array}$ & $\begin{array}{l}97.77 \\
\pm 2.22\end{array}$ & $\begin{array}{l}100.00 \\
\pm 0.00\end{array}$ & \\
\hline$* \mathrm{EPEF}$ & $\begin{array}{l}244.19^{b} \\
\pm 16.16\end{array}$ & $\begin{array}{c}272.96^{\mathrm{a}} \\
\pm 2.40\end{array}$ & $\begin{array}{r}275.19^{\mathrm{a}} \\
\pm 2.79 \\
\end{array}$ & $\begin{array}{c}276.44^{\mathrm{a}} \\
\pm 2.28 \\
\end{array}$ & $\begin{array}{c}275.82^{\mathrm{a}} \\
\pm 8.11 \\
\end{array}$ & $\begin{array}{c}273.39^{\mathrm{a}} \\
\pm 1.94 \\
\end{array}$ & $*$ \\
\hline
\end{tabular}

$a, b, c, d, e$ Means the same raw have the different superscript are significantly different $(P<0.05)$.

S.E: Meaning standard error. N.S: non-significant. 


\section{Hamady et al.}

\section{CONCLUSION}

Supplementation acetic acids (6 and $8 \%$ ) with feed withdrawal ( 8 hours at 22-42 days of age) in broiler chickens diets improved growth performance, immunological status and reduced mortality rate without adverse effect on body functions, this may be due to realizing the best economic production for growing broiler chickens under the Egyptian condition (in summer season).

\section{REFERENCES}

AOAC (2012). Official methods of analysis. Association of Official Analytical Chemists. Washington, D.C.

Abbas, T., M. A. Muneer, M. D. Ahmed, M. A. Khan, M. Younus and I. Khan (2006). Comparative efficacy of five different brands of commercial newcastle disease lasota virus vaccines in broilers Pakistan Vet. J., 26(2): 55-58.

Abdel-Fattah, S.A., M.H.EI-Sanhoury, N.M. EI-Mednay and F. Abdul-Azeem (2008). Thyroid activity, some blood constituents, organs morphology and performance of broiler chicks fed supplemental organic acids. Int. J. Poult. Sci., 7, 215-222.

Adil, S., T. Banday, G. A. Bhat, S. D. Qureshi and S. A. Wani (2011). Effect of supplemental organic acids on growth performance and gut microbial population of broiler chicken. Livest. Res. Rural Dev. $23: 1-8$.

Afsharmanesh, M. and J. Pourreza (2005). Effects of Calcium, Citric Acid, Ascorbic Acid, Vitamin D on the Efficacy of 3 Microbial Phytase in Broiler Starters Fed Wheat-Based Diets I. Performance, Bone Mineralization and Ileal Digestibility Int. J. Poult. Sci., 4, 418-424.

Atapattu, N.S.B.M. and C.J. Nelligaswatta (2005). Effects of Citric Acid on the Performance and the Utilization of Phosphorous and Crude Protein in Broiler Chickens Fed on Rice By-Products Based Diets. Int. J. Poult. Sci., 4, 990-993.

Benyi, K., O. Acheampong-Boateng and D. Norris (2011). Effects of strain and different skip-a-day feed restriction periods on growth performance of broiler chickens. Trop. Anim. Health Prod. 42:14211426.

Bonos, E., E. Christaki, A.Abrahim, N.Soultos and P. Florou-Paneri (2011). The influence of mannan oligosaccharides, acidifiers and their combination on caecal microflora of Japanese quail (Coturnix japonica). Anaerobe, 17, 436-439.

Bordoni, A., A.Amaretti, A.Leonardi, E.Boschetti, F.Danesi and D.Matteuzzi (2013). Cholesterollowering probiotics: In vitro selection and in vivo testing of bifidobacteria. Appl. Microbiol. Biotechnol. 97:8273-8281.

Bronner, F. (1987). Intestinal calcium absorption : mechanisms and applications. J. Nutr., 117, 1347-1352

Decuypere, E. and Bruggeman, V. (2007). The endocrine interface of environmental and egg factors affecting chick quality. Poultry Science 86:1037-1042. https://doi.org/10.1093/ps/86.5.1037

Duncan, D.B. (1955). Multiple range and multiple F-test.Biometrics. 11: 1-42. http://dx.doi.org/10.2307/3001478.

Fukunaga ,T.M., Y.Sasaki, T.Araki, T.Okamoto, T.Yasuoka, Tsujikawa, Y .Fujiyama and T.Bamba (2003). Effects of the soluble fibre pectin on intestinal cell proliferation, fecal short chain fatty acid production and microbial population. Digestion 67: 42-49.

Fushimi, T., K.Suruga, Y. Oshima, M. Fukiharu, Y. Tsukamoto and T. Goda (2006). Dietary acetic acid reduces serum cholesterol and triacylglycerols in rats fed a cholesterol-rich diet. British Journal of Nutrition, 95, 916-924.

Gauthier, R. (2002).I ntestinal health, the key to productivity: (The case of organic acids). IASA XXVII convencion ANECA-WPDC. Puerto Vallarta, Mexico. 
Ghazanfari, S., H. Kermanshahi, M.R. Nassiry, A.Golian, A.R.H. Moussavi and A.Salehi (2010). Effects of feed restriction and different energy and protein levels of the diet on growth performance and growth hormone in broiler chickens. J. Biol. Sci. 10:25-30.(19)

Griminger, P. and C.G. Scanes (1986). Protein metabolism. In: Avian Physiology, Sturkie, P.D.(Ed). $4^{\text {th }}$ Edn., Springer, New York, USA.,pp:326-345.

Guide Cobb 500 (2018).Broiler Performance and Nutrition Supplement. https ://cobbstorage. blob.core.

windows.net > guides.

Havely, O., Y. Nadel, M. Barak, I. Rosenboim and D.Sklan (2003). Early posthatch feeding stimulates satellite cell proliferation and skeletal muscle growth in turkey poults. The Journal of Nutrition 133.5.1376-1382. https://doi.org/10.1093/jn/

Heaney, R. P., R. R. Recker and C. M. Weaver (1990).Absorbability of calcium sources: the limited role of solubility. Calcif. Tissue Int., 46, 300-304

Khajali, F., Q. A. Zamani-Mghaddam and E. Ashadi-Khoshoe (2007). Application of early skip-a-day feed restriction on physiological parameters, carcass traits and development of ascites in male broilers raised under regular and low temperatures at high altitude. Anim. Sci. J. 78:159-163.

Khana, S. H. and J. Iqbalb (2016). Recent advances in the role of organic acids in poultry nutrition. Journal Of Applied Animal Research, Vol. 44, No. 1, 359-369

Lakos, G., L. Soós, A. Fekete, Z. Szabó, M. Zeher, I.F. Horváth, K.Dankó, A.Kapitány, A.Gyetvai, G.Szegedi and Z. Szekanecz (2008). "Anti-cyclic citrullinated peptide antibody isotypes in rheumatoid arthritis: association with disease duration, rheumatoid factor production and the presence of shared epitope". Clinical and Experimental Rheumatology. 26 (2): 253-260. PMID 18565246.

LeBlay, G., H. M. Blottiere, L. Ferrier, E. LeFoll, C. Bonnet, J. P. Galmiche and C. Cherbut (2000). Short-chain fatty acids induce cytoskeletal and extracellular protein modification associated with modulation of proliferation on primary culture of rat intestinal smooth muscle cells. Digestive Disease Science. 45: 1623-1630.

Luckstadt, C. (2007). Acidifiers in animal nutrition. Nottingham University Press. Nottingham, UK.

Mahmud, A., F.M. Khattak, Z. Ali and T.Pasha (2008). Effect of early feed restriction, on broiler performance, meal feeding on performance, carcass characteristics and blood constituents of broiler chickens. J. Anim. Vet. Adv. 8:2069-2074.

Moghadam, A.N., J.Pourreza and A.H. Samie (2006). Effect of Different Levels of Citric Acid on Calcium and Phosphorus Efficiencies in Broiler ChicksPak. J. Biol. Sci., 9, 1250-1256.

NRC (1994). National Research Council. Nutrient requirements of poultry 9th rev. Ed. National Academy Press, Washington, D.C.

Navidshad, B., M. Shivazad, A. Zare and G. Rahim (2006). Effect of feed dietary restriction and fat saturation on performance and serum thyroid hormones in broiler chickens Int. J. Poult. Sci. 5:436440.

Nezhad, Y. E. M.Shivazad, M. Nazeerad and M. M. S. Babak (2007). Influence Of Citric Acid And Microbial Phytase On Performance And Phytate Utilization In Broiler Chicks Fed A Corn-Soybean Meal Diet. J. Fac. Vet. Med. Univ. Tehran., 61, 407-413.

Papatsiros, V. G., C. Cristodoulopoulos and L. C. Filippopoulos (2012). The use of organic acids in monogastric animals (swine and rabbits). J. Cell Anim. Biol. 6:154-159.

Philipsen, I.P.L.J. (2006). Acidifying drinking water supports performance. World Poult. 22:20-21.

Quinn, P. J., M. E. Carter, B. K. Markey and G. R. Carter (1994). Clinical veterinary microbiology, wolf publishing. London (1994) ISBN 0-7234-1711-3.

Richards, M. P., S. M. Poch, C. N. Coon, R. W. Rosebrough, C. M. Ashwell and J. P. McMurty (2003). Feed restriction significantly alters Lipogenic Gene expression in broiler breeder chickens. J. Nutr. 133(3):707-715.

Sarıca, S., M. Suiçmez, M. Çördük, D. Özdemir and E. Berberoglu (2014). Effects of oregano essential oil supplementation to diets of broiler chicks with delayed feeding after hatching. Morphological 


\section{Hamady et al.}

development of small intestine segments. Italian Journal of Animal Science 13:284-289. https://doi.org/10.4081/ijas.2014.3172.

Sarlak, S., S. A. Tabeidian and A. Gheisari (2017). Effects of time of initiation of feeding after hatching and diet composition on performance, carcass characteristics, digestive tract development and immune responses of broilers. Animal Production Science 57:1692-1701. https://doi.org/10.1071/AN15839

Silva De, P.H.G.J. and A. Kalubowila (2012). Influence of Feed Withdrawal for Three Hour Time Period on Growth Performance and Carcass Parameters of Later Stage of Male Broiler Chickens. Iranian Journal of Applied Animal Science. 2 (2), 191-197.

SPSS (2001). SPSS for windows S, Chicago, IL SPSS Computer software 11.00 (2001). SPSS Inc., Headqurters. Wacker Drive,Chicago, Illinois 60606, USA. Pp. 233.

Strauss, G. and R. Hayler (2001). Effects of organic acids on microorganisms. Kraftfutter 4:147-151.

Tallentire C.W., I. Leinonen and I. Kyriazakis (2016). Breeding for efficiency in the broiler chicken. Agron. Sustain. Dev. 36: 66 DOI 10.1007/s13593-016-0398-2

Tolkamp, B.J., V. Sandilands and I. Kyriazakit (2005). The effect of early feed restriction during rearing on the performance of broiler breeders during rearing and lay. Poult. Sci. 84:1286-1293.

Whitehead, C. C. and T. Keller (2003). An update on ascorbic acid in poultry. World's Poult. Sci. J., 59: 161-184.

Yamashita, H., K. Fujisawa, E. Ito, S. Idei, N. Kawaguchi, M.Kimoto, M.Hiemori and H.Tsuji (2007). Improvement of Obesity and Glucose Tolerance by Acetate in Type 2 Diabetic Otsuka Long-Evans Tokushima Fatty (OLETF) Rats. Biosci. Biotechnol. Biochem, 71, 1236-1243.

Yamashita, H., T.Kaneyuki and K.Tagawa (2001). Production of acetate in the liver and its utilization in peripheral tissues. Biochim. Biophys. Acta, 1532, 79-87.

Yang, H., L. Meng, D. Ai, N. Hou, H. Li, X. Shuai and X. Peng (2019). Acetic acid alleviates the inflammatory response and liver injury in septic mice by increasing the expression of TRIM40. Experimental and therapeutic medicine, 17: 2789-2798.

Zhan, X. A., M. Wang, H. Ren, Q.R. Zhao, J.X. Li and Z. L. Tan (2007). Effect of early feed restriction on metabolic programming and compensatory growth in broiler chickens. Poult. Sci., 86:645 -660.

Zubair, A. K. and S. Leeson (1996). Changes in body composition and adipocyte cellularity of male broilers subjected to varying degrees early-life feed restriction. Poult. Sci., 75:719-728. 


\author{
جمال على عبدالحافظ حمادى ، مسعد فوزى طبوشة و محمد يوسف محمد على \\ قسم الانتاج العيوانس_ كلية الزراعة - جامعة الازهر- القاهرة - مصر.
}

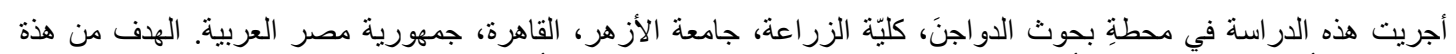

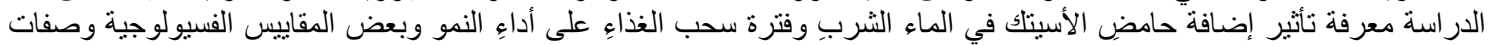

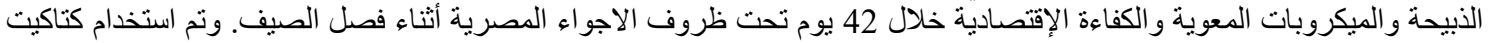

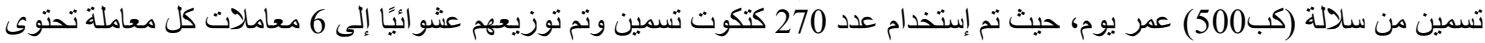
على 3 مكررات كل مكررة تحتوى على 15 طائر. و وكانت المعاملات كالتالى: المجمو عة الأولى: مجمو عة المقارنة في الظروف المثلى (تغذية حرة حتى الثبع من خلال دليل سلالة كب 500). المجمو عة الثانية: تصويم الطيور عن العلف 8 ساعات يو ميا (9.00 صباحا - 5.00 مساءً) خلال (22-42) يوم. المجمو عة الثالثة: إضافة حامض الاسيتك بنسبة 6\% خلان

المجمو عة الر ابعة: تصويم الطيور عن العلف 8 ساعات يوميا (9.00 صباحا - 5.00 مساءً) مع إضافة حامض الاسيتك بنسبة 6\% خلال

المجمو عة الخامسة: إضافة حامض الاسيتلك بنسبة 8\% خلال (22-42) يوم.

المجمو عة السادسة: تصويم الطيور عن العلف 8 ساعات يوميا (9.00 صباحا ـ5.00 مساءً) مع إضافة حامض الاسيتك بنسبة 8\% خلال

النَتائج المكتسبة لُخّصت كالاتى:

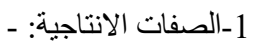

ـ كان وزن الجسم النهائى و الزيادة فى وزن الجسم عند 42 يوم أعلى معنويا فى المعاملة الخامسة وكانت المعاملة الثانية أقل المعاملات من

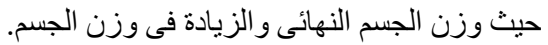

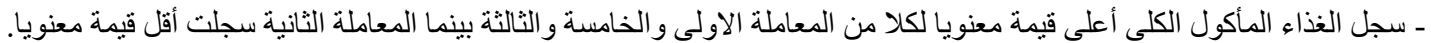

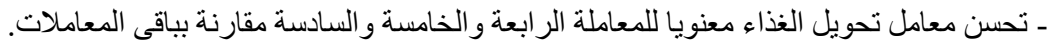
ـ نسبة النفوق كانت أعلى فى المعاملة الاولى تليها المعاملة الخامسة مقارنة بياقى المعاملات المعات.

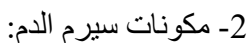
ـ كان البروتين الكلى غير معنويات الامى في جميع المعملات. بالإضافة الى أن نسبة الألبيومين كانت أعلى معنويا فى المعاملة الاولى مقارنة

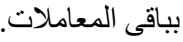
ـ الكليسترول الكلى والكليسترول منخفض الكثاف الكافة و الدهون الكلية والجليسريدات الثلاثية ومعدل إنزيم AST ومعدل Igg تاثر معنويا بالارتفاع بالمعاملة الاولى و انخفض بإضافة حامض الاسيتلك أوسحب الغذاء.

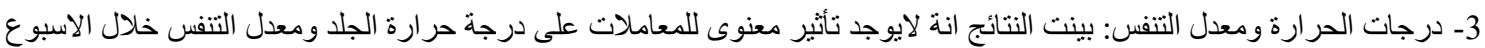

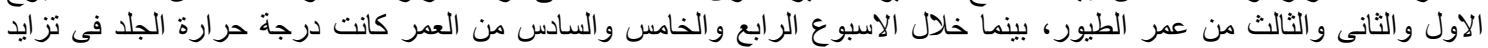

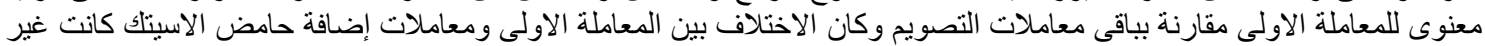

معنوية.

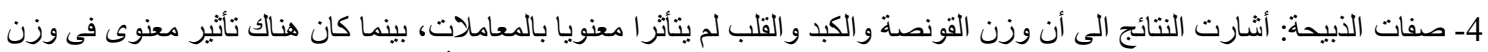

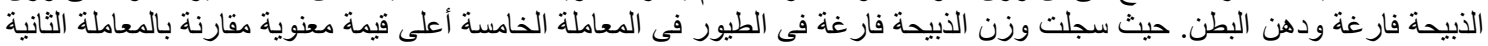

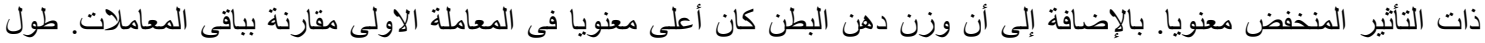

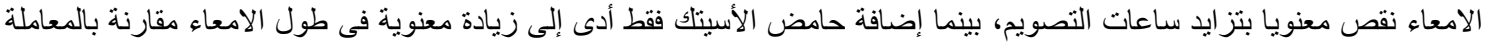

الثانية.

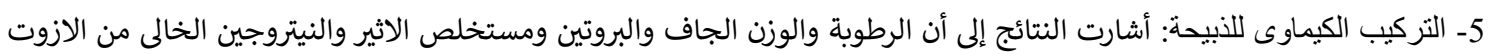

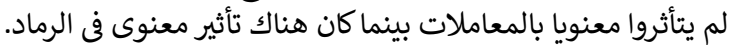

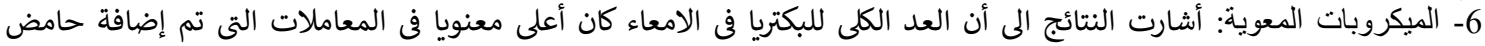

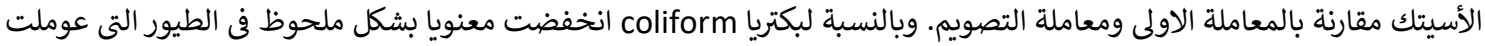

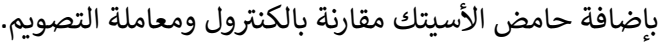
7ـ الكفائة الاقتصادية: أشارت النتائج الى أن معامل كفاءة الإنتاج الاوروبى تزايد بشكل ملحوظ لكل معالجة ماعدا الكنترول.

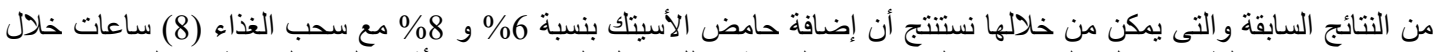

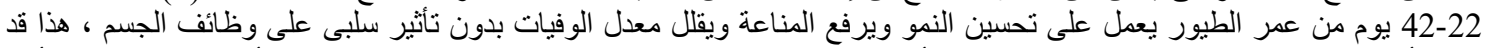

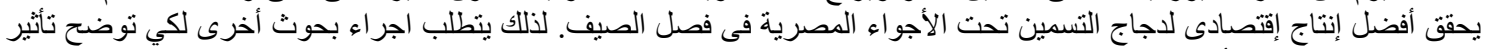
التفاعل بين مستويات الأحماض العضاج لإج لإنية وساعات سحب الغذاء. 